\title{
The Effect of Urea Molasses Multi-Nutrient and Medicated Block for Beef Cattle, Beef and Dairy Cow
}

\author{
Suharyono ${ }^{1}$, H. Sutanto ${ }^{2}$, Y. Purwanti ${ }^{3}$, Martanti ${ }^{3}$, A. Agus ${ }^{3}$ and R. Utomo ${ }^{3}$ \\ ${ }^{I}$ Center for Isotopes and Radiation Application, National Nuclear Energy Agency, \\ Jl. Lebak Bulus Raya No. 49, Jakarta 12440, Indonesia \\ ${ }^{2}$ Faculty of Animal Husbandry, Brawijaya University, Jl. Veteran, Malang 65145, Indonesia \\ ${ }^{3}$ Faculty of Animal Science Gajah Mada University, Jl. Fauna Street No. 3 Bulaksumur, Yogyakarta 5528, Indonesia
}

\section{ARTICLE INFO}

\section{Article history:}

Received 28 January 2014

Received in revised form 13 June 2014

Accepted 23 June 2014

\section{Keywords:}

UMMB

Protein

Tracer

Medicated

Herbal

Anthelmintic

\begin{abstract}
A B S T R A C T
Urea molasses multi-nutrient block (UMMB) is a feed supplement and one of the best formulas constructed by the National Nuclear Energy Agency (BATAN). This supplement contains soya bean meal (SBM) and has been developed using different protein sources, such as Enterolobium cyclocarpum (Ec), soya bean waste sauce (SBWs), wheat pollard (WP) and WP bypass protein (WPBp). It has also been developed using medicated block (MB). The objective is to introduce the P-32 tracer for obtaining a new feed supplement, to apply UMMB-SBM on beef cattle for fattening, and to test UMMB-MB on cows in the field. Parameters measured include microbial protein synthesis (MPS) in rumen liquid, daily live weight gain (DLWG), milk production and total count of worm in feces. Statistical analysis used were Latin squares, Student's t-test, and completely randomized design. The UMMBSBM was better than UMMB-Ec, UMMB-SBWs, and UMMB-WP, because it was able to increase MPS by up to $205.67 \%$, superior to the other feed supplements $(51.01 \%, 34.04 \%$, and $73.94 \%$ respectively). On the other hand, with UMMBWPBp supplementation, MPS was enhanced by $425.27 \%$. The UMMB-SBM was able to increase DLWG by $0.34,0.30,0.38$ and $0.36 \mathrm{~kg} / \mathrm{head} / \mathrm{d}$ on Bali cattle, Ongole, Simmental, and Frisian Holstein cross breed respectively. The increase of cost benefit ratio was affected by increasing DLWG. These values were 1:1.89; 1 : 1.34; $1: 1.45$ and 1:1.35 respectively. UMMB-MB-C. aeruginosa and albendazole increased milk production by $4.23 \%$ and $46.56 \%$, respectively. In the first communal group, beef cows that received UMMB-MB albendazole were able to increase feed consumption, including dry matter, organic matter, crude protein, and total digestible nutrient, at $\mathrm{P}<0.05$. The second communal group, feed consumption significantly differed from control at $\mathrm{P}<0.05$ on crude protein, and total digestible nutrient. UMMB-MB tends to be effective only for ten days on the total amount of egg worm in feces.
\end{abstract}

\section{INTRODUCTION}

The feed supplement Urea-Molasses Multinutrient Block (UMMB) was a result of studies at the Centre for the Application of Isotopes and Radiation (CAIR), BATAN by several research workers, and it has been presented in several papers $[1,2]$. The best formula selected was obtained by using P-32 tracer to determine microbial protein synthesis in the rumen liquid $[3,4]$.

The introduction of UMMB has been undertaken in the field in several provinces of Indonesia, namely which Central Java, West Java, East Java, and West Nusa Tenggara.

\footnotetext{
* Corresponding author.

E-mail address: suharyono@batan.go.id
}

The researchers reported that UMMB supplementation increased daily live-weight gain, milk production, milk quality and reproductive performance [5-7]. In several countries, it has been used as a feed supplement for beef cattle, dairy cows and a small ruminant [8]. The UMMB feed supplement is not only applied on ruminant animals, but also introduced to the farmers in order to create a small business. The results showed that it has economic benefits for farmers in a short time of three months $[9,10]$. The introduction of UMMB in the field gathered information about the available local feed resources which could be used for composing new formulas of feed supplement related to the areas where their test were carried out. Some materials, including agricultural and industrial byproducts, leguminous leaves, herbal and 
anthelmintic agents, have a potential role for further explorations of their benefits when used as feed supplements for ruminant animals. Other information obtained in the field was about internal parasitic infection in beef and dairy cows that could decrease their productivity [11]. By addition of medicated urea, molasses multinutrient blocks were able to increase milk production of dairy cows and buffaloes [12]. The studies have indicated that the use of medicated blocks in dairy cows decreased internal parasitic burden and improved the persistence of the lactation curve [13]. Regarding all information, three activities were carried out. The first activity was a review of the utilization of tracer of P-32 for biological evaluation of formulas of feed supplements that contain protein sources from soybean waste sauce (SBWs), Wheat Pollard (WP) and Enterolobium cyclocarpum (Ec) compared to UMMB-SBM. The second activity was the development of UMMB application on some breeds of beef cattle in difference areas. The third activity was the test of UMMB-MB on beef and dairy cows.

The overall objectives of the current project are to review the utilization of tracer of P-32 for obtaining other feed supplement, to develop UMMB on some breeds of beef cattle for fattening at difference areas, and to utilize medicated block (UMMB-MB) herbal and anthelmintic for parasite control as well, so that the productivity of beef and dairy cows could be expected to increase.

\section{EXPERIMENTAL METHODS}

The activities of research were conducted in laboratory-scale and field trials. These were in vitro and in vivo studies respectively. Biological evaluation of feed supplement for measuring microbial protein synthesis (MPS) were carried out in vitro, whereas in vivo for testing UMMB-SBM and UMMB medicated block (UMMB-MB) in field.

\section{Biological evaluation of feed supplement}

The MPS in the rumen liquid of etawa cross breed (CB) dairy goat, buffaloes and beef cattle had been measured by using P-32 tracer. These animals were supplied feed supplements UMMB-SBM, UMMB-Ec, UMMB-SBWs, UMMB-WP, and UMMB-WPBp.

\section{Development of UMMB application on some breeds of cattle}

The activities of the pilot project of UMMB feed supplement were carried out in several provinces of Indonesia, namely Central Java, Yogyakarta, East Java, Bali, West Nusa Tenggara, South Sumatra, West Sumatra and South Sulawesi. Those activities are presented in Tables 1 .

Table 1. The UMMB supplementation of beef cattle for fattening program at various provinces in Indonesia.

\begin{tabular}{clcc}
\hline No. & Name of provinces & No $\left.{ }^{*}\right)$ & Breeds \\
\hline 1 & Bali & 20 & Bali \\
& & 12 & Bali \\
2 & West Nusa Tenggara & 16 & Bali \\
3 & South Sulawesi & 20 & Bali \\
4 & Central Java & 12 & Ongole CB \\
& & 16 & Ongole CB \\
& & 10 & Simental CB \\
5 & Yogyakarta & 10 & Ongole CB \\
& & 16 & Simental CB \\
6 & South Sumatra & 12 & Ongole CB \\
7 & West Sumatra & 20 & Simental CB \\
& & 20 & Simental CB \\
8 & Central Java & 20 & FH CB \\
& & 16 & FH CB \\
& & 12 & FH CB \\
9 & West Sumatra & 8 & FH CB \\
\hline *) Total amount of animal used & &
\end{tabular}

These were different from previous UMMB application. These distinguished was shown on different location, and animal breed used. The UMMB supplementation was evaluated more extensively with males of Fries Holstein (FH) cross breed (CB) and beef cattle for fattening program. As a general procedure, the available beef cattle were allocated randomly into two groups, namely a control group that received the roughage and concentrate that were normally fed to beef cattle on the location and a second group which received the same diet as the control group with the addition of UMMB as a supplement at the rate of $0.1 \%$ of their body weight. Growth rate was measured at monthly intervals during three months. Results were analyzed using Student's t test [14].

\section{Test of UMMB-MB (medicated block) on beef and dairy cows}

The UMMB-MB is one of the feed supplements developed from UMMB by adding an anthelmintic and a herbal agent. These are albendazole and Curcuma aeruginosa (C. aeruginosa), respectively. The dose of the agent in the UMMB was either $5 \mathrm{~g} / 80 \mathrm{~kg} / \mathrm{head}$ or $21 \mathrm{~g} / 500 \mathrm{~g} / \mathrm{head}$ respectively. These were tested in Yogyakarta at four locations and East Java Provinces in one location. At each location in Yogyakarta, the UMMB-MB was applied to nine and twelve animals, whereas at the location in East Java six animals received UMMB-MB.

The experimental animals used in Yogyakarta were dairy cows of $\mathrm{FH} \mathrm{CB}$ and beef cows 
Simmental Ongole (SIMPO) CB, whereas in East Java only dairy cows of FH CB was used. Beef and dairy cows were given UMMB-MB which contained herbal and anthelmintic medicine. The $C$. aeruginosa was given to dairy cows in East Java and beef cows in Yogyakarta (Sleman and Gunung Kidul). The UMMB-MB that contained albendazole was feed to dairy cows in Yogyakarta (Sleman), including beef cows in Bantul 1 (Manunggal Karyo) and Bantul 2 (Andini Mulyo). Manunggal Karyo and Andini Mulyo are the name of communal groups at Bantul.

\section{Test of UMMB-MB on dairy cows}

Treatment of UMMB-MB supplementation on dairy cows in both East Java and Yogyakarta was divided into three groups of six cows and nine cows respectively. The first group acted as a control that received normal feed usually given by farmers. The second group was supplemented with UMMB and the third group was as the first group plus UMMB-MB-C. aeruginosa or albendazole. Each animal in the group treatment was given $500 \mathrm{~g} /$ day of both UMMB and UMMB-MB. Regarding the UMMB-MB treatment, cows were only supplemented once in 5 days on the first week a long of the duration14 weeks. Milk production was recorded per day and intake feed was also measured.

\section{Test of UMMB-MB-C. aeruginosa on beef cows}

The activities were conducted at Sleman and Gunung Kidul, Yogyakarta and used SIMPO cross breed respectively. The treatments were the same as test of UMMB-MB on beef cows in Bantul. This was distinguished from group III where UMMBMB-C. aeruginosa was supplied.

The process of this block was identical as UMMB, but to the composition was added $5 \mathrm{~g}$ albendazole/80 $\mathrm{kg}$ body weight or $21 \mathrm{~g} C$. aeruginosa $/ 500 \mathrm{~g}$ UMMB. The medicated block (MB) was given to the experimental animals and only for 3-5 days from the beginning of the treatment. The parameters measured consist of dry matter, organic matter, crude protein and total digestible nutrient consumption, and also feed composition and daily live weight gain. The experimental design used was a completely randomized design; afterward, the data was analyzed by Duncan's multiple range tests to determine if any significant difference occurred among the treatments [14].

\section{Test of UMMB-MB-Albendazol on beef cows}

A treatment with UMMB-MB-Albendazole was given to Simental Ongole cross breed (SIMPO). The SIMPO beef cows were identified approximately six weeks after calving. The cows were used as experimental animals that were kept at Bantul 1. Nine beef cows were randomly assigned into three groups. Group I received a basal diet and concentrate mixture based on daily feed used by farmers as control. Feed treatments are presented in Table 2.

Table 2. Feed treatment at Bantul 1.

\begin{tabular}{cccc}
\hline Group & $\begin{array}{c}\text { Feed } \\
\text { treatment }\end{array}$ & Feed supplement & Remarks \\
\hline I & Control & - & $\begin{array}{c}\text { daily feed used } \\
\text { by farmers } \\
\text { Given every day }\end{array}$ \\
II & I & $\begin{array}{c}500 \mathrm{~g} \\
\text { UMMB/head/d }\end{array}$ & $\begin{array}{c}500 \mathrm{~g} \mathrm{UMMB}-\mathrm{MB}- \\
\text { Albendazol }\end{array}$ \\
III & I & $\begin{array}{c}5 \mathrm{~g} / 80 \mathrm{~kg} \text { body } \\
\text { weight }\end{array}$ \\
\hline
\end{tabular}

The UMMB-MB treatment at Bantul 2 used twelve Ongole beef cows cross breed that were divided randomly into four treatment diet groups. The first group was ration I (R1) as control that was fed as usually given by farmers. The details of feed treatments are shown in Table 3.

Table 3. Feed treatment at Bantul 2.

\begin{tabular}{|c|c|c|c|}
\hline Ration & $\begin{array}{c}\text { Feed } \\
\text { treatments }\end{array}$ & Feed supplement & Remarks \\
\hline I & Control & - & $\begin{array}{l}\text { Feed as given } \\
\text { every day by } \\
\text { farmers }\end{array}$ \\
\hline II & I & Albendazole & $\begin{array}{c}5 \mathrm{~g} / 80 \mathrm{~kg} \text { body } \\
\text { weight }\end{array}$ \\
\hline III & I & $500 \mathrm{~g} \mathrm{UMMB} / \mathrm{head} / \mathrm{d}$ & Given every day \\
\hline IV & I & $\begin{array}{l}500 \mathrm{~g} \text { UMMB-MB- } \\
\text { Albendazole }\end{array}$ & $\begin{array}{c}5 \mathrm{~g} / 80 \mathrm{~kg} \text { body } \\
\text { weight }\end{array}$ \\
\hline
\end{tabular}

The cows were maintained at a communal group at Andini Mulyo, Bantul 2, Yogyakarta. Beef cows were monitored over three months for live-weight change and rectal faecal samples were taken at 0, 10, 30, 60 and 100 days for faecal worm eggs count [15].

\section{RESULTS AND DISCUSSION}

\section{Biological evaluation of feed supplement using tracer P-32}

The results of previous studies of MPS in rumen liquid of etawa dairy goat $\mathrm{CB}$, buffaloes and cattle are presented in Table 4.

The MPS in the rumen liquid of these animals increased due to the feed supplement supplied. It seems that UMMB-SBM supplementation 
increased MPS by up to $67.56 \%, 205.67 \%$ and $37.99 \%$. The UMMB-Ec increased MPS by $51.01 \%$ and $292.65 \%$, whereas UMMB-WPBp given increased MPS by up to 425.27. Kapok seed meal as bypass protein was a component in the UMMB-WP.

Table 4. Microbial protein synthesis in rumen liquid due to UMMB supplementation with different protein sources (mg/l/hour)*

\begin{tabular}{|c|c|c|c|}
\hline \multicolumn{2}{|l|}{ Feed treatments } & $\begin{array}{c}\begin{array}{c}\text { MPS } \\
\text { (mg/l/hour) }\end{array} \\
\text { Etawa dairy } \\
\text { goat CB }\end{array}$ & $\begin{array}{c}\text { Increase } \\
(\%)\end{array}$ \\
\hline \multicolumn{2}{|l|}{ NG } & 77.94 & - \\
\hline \multicolumn{2}{|c|}{ NG+UMMB-SBM } & 130.6 & 67.56 \\
\hline \multirow{2}{*}{\multicolumn{2}{|c|}{ NG+UMMB-Ec }} & 117.7 & 51.01 \\
\hline & & Buffaloes & \\
\hline \multicolumn{2}{|l|}{ NG } & 142 & \\
\hline \multicolumn{2}{|l|}{ UMMB-WP } & 247 & 73.94 \\
\hline \multicolumn{2}{|l|}{ NG } & 65.3 & - \\
\hline \multicolumn{2}{|c|}{ NG+UMMB-SBM } & 199.6 & 205.67 \\
\hline \multicolumn{2}{|c|}{ NG+UMMB-SBM+Ec+Conc } & 256.4 & 292.65 \\
\hline \multicolumn{2}{|l|}{ UMMB-WPBp } & 343 & 425.27 \\
\hline & & Beef Cattle & \\
\hline \multicolumn{2}{|l|}{ NG } & 189.5 & - \\
\hline \multicolumn{2}{|c|}{ NG+UMMB-SBSw } & 254 & 34.04 \\
\hline \multicolumn{2}{|c|}{ NG+UMMB-SBM } & 261.5 & 37.99 \\
\hline \multicolumn{4}{|c|}{ *) Source : Suharyono [16-19] } \\
\hline MPS & \multicolumn{3}{|c|}{ Microbial protein synthesis } \\
\hline NG & \multicolumn{3}{|c|}{ Native grass } \\
\hline SBM & \multicolumn{3}{|c|}{ Soy bean meal } \\
\hline SBWs & \multicolumn{3}{|c|}{ Soy bean waste sauce } \\
\hline Ec & \multicolumn{3}{|c|}{ Entrolibium cyclocarpum } \\
\hline WP & \multicolumn{3}{|c|}{ Wheat pollard } \\
\hline WPBp & \multicolumn{3}{|c|}{ Wheat pollard_bypass protein } \\
\hline
\end{tabular}

A perusal of Table 4 showed that the increase of MPS was capable of increasing $292.65 \%$, when the animals were given UMMB$\mathrm{SBM}+\mathrm{Ec}+$ concentrate. It means that additional meal of Ec, SBM and concentrate contributed to supply defaunation agent, bypass protein and energy. Leng et al. (1992) reported that leaf of $\mathrm{Ec}$ is able to reduce protozoa amount in rumen liquid [20]. Supplying of protein and energy ratio for ruminant animal in balance condition would enhance daily live weight gain and milk production $[1,2,20]$. With the feed supplements of UMMB-Ec and UMMBWPBp, the increase of MPS in rumen liquid tend to be higher than when UMMB-SBM was given. These were 292.65 and $425.27 \%$ compared to $205.67 \%$. On the other hand, UMMB-Ec and WPBp could not applied in the field as the leaf of Ec powder, WP and kapok seed meal were difficult to obtain for composing an adequate amount of feed supplement. Therefore, UMMB-SBM are used as standard for getting others feed supplement.

\section{Development of UMMB application on some breeds of cattle}

The results of UMMB supplementation on DLWG in beef cattle are shown in Table 5.

Table 5. Average of increase DLWG Bali cattle, Ongole and Simmental and FH CB (kg/head/d).

\begin{tabular}{lccccc}
\hline & \multicolumn{3}{c}{$\begin{array}{c}\text { Average of DLWG } \\
\text { (kg/head/d) }\end{array}$} & \multicolumn{2}{c}{ Profit } \\
\cline { 2 - 6 } $\begin{array}{l}\text { Experimental } \\
\text { animals }\end{array}$ & $\begin{array}{c}+ \\
\text { UMMB } \\
\text { (A) }\end{array}$ & $\begin{array}{c}+ \text { UMMB } \\
(\mathrm{B})\end{array}$ & (B-A) & B/C & $\begin{array}{c}\text { Rp./ } \\
\text { head/d }\end{array}$ \\
\hline Bali cattle & $0.28^{\mathrm{a}}$ & $0.62^{\mathrm{b}}$ & 0.34 & $1: 1.89$ & 2682.5 \\
Ongole CB & $0.35^{\mathrm{a}}$ & $0.65^{\mathrm{b}}$ & 0.30 & $1: 1.34$ & 1202.5 \\
Simmental CB & $0.68^{\mathrm{a}}$ & $1.06^{\mathrm{b}}$ & 0.33 & $1: 1.45$ & 1850 \\
FH CB & $0.63^{\mathrm{a}}$ & $0.99^{\mathrm{b}}$ & 0.36 & $1: 1.35$ & 1480
\end{tabular}

Within lines means different superscript differed significantly $\mathrm{P}<0.05$. DLWG: Daily live weight gain

Daily live-weight gain of unsupplemented Bali cattle was $0.28 \mathrm{~kg} / \mathrm{head} / \mathrm{d}$, whereas the group that received UMMB was $0.62 \mathrm{~kg} / \mathrm{head} / \mathrm{d}$. A similar response to supplementation also occurred on the increase of DLWG of Ongole, Simmental and FH CB. The increase of DLWG was higher with than without supplement. The values were $0.65,1.06$ and $0.99 \mathrm{~kg} / \mathrm{head} / \mathrm{d}$ compared to without supplement $0.35, \quad 0.68$ and $0.63 \mathrm{~kg} / \mathrm{head} / \mathrm{d}$ respectively. The cost-benefit ratio was calculated as proportion of additional net economic gain (Table 5).

The cost-benefit ratio for Bali cattle was higher than for the other breeds used in this study, namely Ongole, Simmental and FH cross-breed (Table 5). Bali cattle are indigenous Indonesia. They have a higher dressing percentage than Brahman and Ongole CB. The dressing percentage was $56 \%, 54 \%$, and $45 \%$ respectively [21].

The UMMB was not only introduced to be applied to beef cattle; instead, training courses on UMMB were also given to farmers and trainers. Participants came from Central Java, Yogyakarta, Bali, West Nusa Tenggara, West Sumatra, South Sumatra and South Sulawesi. The material presented in the course was not only theoretical but also practical, such as making UMMB and standard operational procedure to be done for ruminant animals (beef and dairy cattle, buffaloes, goat and sheep). This feed supplement is easy to make and is an appropriate technology and beneficial for farmers. Based on this they are expected to be able to produce UMMB and build small business. After having been trained, the local farmer groups and farmer cooperatives should be encouraged to manufacture UMMB using locally available resources. In Central Java, Bali and Yogyakarta, some farmers also ventured into UMMB manufacturing as a business enterprise. From these 
trials, UMMB's business resulted in additional farmer income of Rp. 150,765-Rp.301,625/month [22]. The outcome of the introduction of UMMB include not only increased productivity of beef cattle but also potential job creation for farmers.

Due to differences in the feed resources available locally, the composition of the blocks made in Yogyakarta, Central Java, East Java, West Java, West Sumatra, Bali and South Sulawesi were different from the formula used by BATAN. This is assumed to have a good effect on the sustainability of the technology. In some areas the price of materials use for UMMB is cheap, therefore quality and availability of UMMB will be guaranteed and sustainable in the future. The specific materials for the composition of UMMB locally are different from BATAN's UMMB (Table 6).

Table 6. Nutrition source of UMMB composition (\%).

\begin{tabular}{lcccc}
\hline $\begin{array}{l}\text { Formula } \\
\text { BATANs }\end{array}$ & $\begin{array}{c}\text { Carbo- } \\
\text { hydrate }\end{array}$ & Protein & $\begin{array}{c}\text { Non } \\
\text { Protein } \\
\text { nitrogen }\end{array}$ & Mineral \\
\hline Molasses & 33 & - & - & - \\
Rice bran & 18 & - & - & - \\
Tapioca waste & 6 & - & - & - \\
Soy bean meal & - & 13 & - & - \\
Lime stone & - & - & - & 6 \\
Salt & - & - & - & 7.5 \\
Bone meal & - & - & - & 6 \\
Urea & - & - & 4.25 & - \\
Lacta mineral & - & - & - & 1.25 \\
\hline Source: Suharyono, 2010 [22] and BATAN (2005) [23].
\end{tabular}

The illustration in Table 6 indicates that UMMB has a multi-nutrient content as it contains carbohydrate, protein, non-protein nitrogen, and minerals coming from materials such as byproducts of agriculture and agriculture industries.

Farmers from different areas have made UMMB which differed in certain nutrition sources. For example, in Central Java, Yogyakarta, and West Java, as protein source, soybean powder is used as a substitute for soybean meal. In East Java, the soybean meal is replaced by kapok seed meal and wheat pollard as a protein source. In West Sumatra and South Sulawesi, soy bean meal is replaced with oil coconut cake. Molasses as a carbohydrate source has been used for making UMMB composition in some provinces as previously mentioned, except West Sumatra where saka is used. Saka is liquid sugar from sugar palm and it is a traditional sugar which is found in West Sumatra. UMMB not only has a multi-nutrient content but it is also formed as a solid block form which could be licked by ruminant animals every day. In East Java, West Sumatra and South Sulawesi, cement is used to make a solid form. The quality of the block is indicated by its protein, dry matter and ash content (Table 7).

Table 7. Nutrient Content $(\mathrm{g} / \mathrm{Kg} \mathrm{DM})$ of UMMB made in some areas.

\begin{tabular}{lcccc}
\hline & \multicolumn{4}{c}{ Nutrient content $(\mathrm{g} / \mathrm{kg})$} \\
\cline { 2 - 5 } UMMB & $\begin{array}{c}\text { Dry } \\
\text { matter }\end{array}$ & $\begin{array}{l}\text { Organic } \\
\text { matter }\end{array}$ & Ash & $\begin{array}{c}\text { Crude } \\
\text { protein }\end{array}$ \\
\hline Jakarta & 730.12 & 671.14 & 328.90 & 230 \\
(BATAN) & 777.40 & 657 & 343 & 237 \\
& 728.83 & 599 & 401 & 200 \\
Central & 758.21 & 730.31 & 269.71 & 235 \\
Java & 827.83 & 698.13 & 311.93 & 255.60 \\
Yogyakarta & 767.91 & 676.72 & 323.37 & 300 \\
West Java & 820 & 700.52 & 299.52 & 227.94 \\
\hline
\end{tabular}

The protein content of BATAN's UMMB ranges from $200 \mathrm{~g} / \mathrm{kg}$ to $237 \mathrm{~g} / \mathrm{kg}$, whereas for Central Java, Yogyakarta and West Java, the range is $227.94-300 \mathrm{~g} / \mathrm{kg}$. The ash which is representative of the mineral source in UMMB show different values for different blocks. For BATAN, the ash content of the block is $328.90-401 \mathrm{~g} / \mathrm{kg}$, which is higher than in blocks found in Central Java, Yogyakarta and West Java, which are 269.71, 323.37 and $299.52 \mathrm{~g} / \mathrm{kg}$ respectively. The dry matter content of BATAN's UMMB is lower than UMMB from Central Java, Yogyakarta and West Java. Their values is in the $728.83-777.40 \mathrm{~g} / \mathrm{kg}$ range compared to $758.21-827.83 \mathrm{~g} / \mathrm{kg}$ respectively. Mold does not grow well, when UMMB is wrapped in plastic bags properly.

The lower or higher crude protein content of the UMMB formula reflects the lower or higher crude protein content of the ingredients used. Soybean meal is a byproduct of soybean oil; indeed it will be different with powder of soybean. Crude protein content is $29.33 \%$ and $32.33 \%$ respectively [22]. The ash concentration reflects mineral content in feed; the higher ash content, the higher the mineral in feed. The mineral content of UMMB usually includes potassium $(\mathrm{K})$, cobalt $(\mathrm{Co})$ and sulfur (S) [24]. In addition, it was reported that Co and $\mathrm{S}$ are minerals essential for growing microbial in rumen liquid $[2,25]$. The dry matter content of BATAN's UMMB was under $86 \%$, meaning that water content was higher and made it easier to be contaminated by mold. The standard of water content in feed is $14 \%$ [26].

\section{Test of UMMB-MB (medicated block) on beef and dairy cows}

The results of feed supplement UMMB-MB C. aeruginosa test are presented in Table 8, whereas for the suplementation with UMMB-MBalbendazole, the results are given in Table 9. 
In Table 8 it is given that milk production tends to increase $14.20 \quad 1 / \mathrm{head} / \mathrm{d}$ when dairy cows were supplied with UMMB-MB- $C$. aeruginosa. However, when they were supplied with UMMB and control feed, milk production were 16.14 and $13.60 \mathrm{l} / \mathrm{head} / \mathrm{d}$, respectively. It means that the increase of milk production was $4.23 \%$ and $15.74 \%$ compared to control feed.

Table 8. The effect of UMMB-MB-C. aeruginosa on milk production.

\begin{tabular}{|c|c|c|c|}
\hline $\begin{array}{l}\text { Place } \\
\text { East Java }\end{array}$ & Control & $\begin{array}{l} \\
\text { UMMB } \\
\text { Dairy cows }\end{array}$ & $\begin{array}{l}\text { UMMB-MB - } \\
\text { C. aeruginosa } \\
\text { s }\end{array}$ \\
\hline Intake of forages $(\mathrm{kg} / \mathrm{d})$ & 9.50 & 7.95 & 8.25 \\
\hline $\begin{array}{l}\text { Intake of concentrate } \\
(\mathrm{kg} / \mathrm{d})\end{array}$ & 5.20 & 5.81 & 5.47 \\
\hline $\begin{array}{l}\text { Milk production } \\
(1 / \text { head/d })\end{array}$ & 13.60 & 16.14 & 14.20 \\
\hline
\end{tabular}

Table 9. Intake, growth and milk production in dairy cows supplemented with UMMB and UMMB-MB- albendazole.

\begin{tabular}{lccc}
\hline \multicolumn{1}{c}{ Places } & Control & $\begin{array}{c}\text { UMMB } \\
\text { Dairy cows }\end{array}$ & $\begin{array}{c}\text { UMMB-MB- } \\
\text { Albendazol }\end{array}$ \\
Yogyakarta & \multicolumn{3}{c}{8.25} \\
\hline Intake of forages $(\mathrm{kg} / \mathrm{d})$ & 7.35 & 7.95 & 6.43 \\
Intake of concentrate $(\mathrm{kg} / \mathrm{d})$ & 6.43 & 6.18 & 10.11 \\
$\begin{array}{l}\text { Milk Production }(\mathrm{l} / \mathrm{head} / \mathrm{d} \\
\text { Mean of increase milk }\end{array}$ & 10.81 & 11.43 & $1.31^{\mathrm{b}}$ \\
$\begin{array}{l}\text { production }(1 / \text { head/d) } \\
\begin{array}{l}\text { Average daily weight gain } \\
\text { (kg/head/d) }\end{array}\end{array}$ & $0.70^{\mathrm{a}}$ & $0.81^{\mathrm{a}}$ & -0.20 \\
\hline $\begin{array}{l}\text { Within lines, different subscription means significantly } \\
(\mathrm{P}<0.05) .\end{array}$ & difference \\
& & &
\end{tabular}

Supplementation of UMMB-MB-albendazole and UMMB on dairy cows increased the average of milk production up to 1.31 and $0.81 \mathrm{l} / \mathrm{head} / \mathrm{d}$ compared to $0.70 \mathrm{l} / \mathrm{head} / \mathrm{d}$ (control). The increase with UMMBMB-albendazole was $46.56 \%$ while with UMMB alone it was $13.58 \%$. Recent evidence from studies in Europe, North America and Australia indicate that in high producing dairy cow significant production losses can occur even when very low levels of nematode infections are evident. This is thought to be due to the nutrient cost of the immune response in suppressing worm egg output and possibly worm establishment. Similar results have been shown to occur in Indian dairy cattle [27]. In the present study with UMMB-MB- $C$. aeruginosa, there did not appear to be any additional benefits from inclusion of this herbal remedy in the UMMB formulation. This may be due to the lack of anthelmintic effects of this herb in this formulation or insufficient parasites to warrant treatment. Further studies should be conducted to confirm these observations.

In contrast to the results for the herbal preparation, with UMMB-MB-albendazole, the treatment resulted in a high increase in milk production. In this study UMMB alone increased milk production by $13.58 \%$, whereas cows receiving UMMB-MB-albendazole increased milk production by up to $46.56 \%$ compared to cows receiving the control diet. This response is similar to other studies with dairy cows [12] where negligible levels of nematode eggs were present in the feces.

The DLWG of beef cows was supplied by $\mathrm{UMMB}$ and UMMB-MB-C. aeruginosa tend to increase from 0.14 to $0.15 \mathrm{~kg} / \mathrm{head} / \mathrm{d}$, whereas in the control it was only $0.11 \mathrm{~kg} / \mathrm{head} / \mathrm{d}$. Beef cows in other places which have been given UMMB and treated with $C$. aeruginosa decreased their body weight by $0.17 \mathrm{~kg} / \mathrm{head} / \mathrm{d}$ (Table 10) compared to control, the decrease was $-0.37 \mathrm{~kg} / \mathrm{head} / \mathrm{d}$.

Table 10. Intake and growth in beef cows were supplemented with UMMB-MB-C. aeruginosa.

\begin{tabular}{lcll}
\hline \multicolumn{1}{c}{ Places } & Control & UMMB & $\begin{array}{l}\text { UMMB -MB-C } \\
\text { aeruginosa }\end{array}$ \\
\hline $\begin{array}{l}\text { Gunung Kidul } \\
\text { Yogyakarta }\end{array}$ & \multicolumn{3}{c}{ Beef Cows } \\
\hline $\begin{array}{l}\text { Intake of forages (kg/d) } \\
\text { Intake of concentrate }\end{array}$ & 5.40 & 6.84 & 6.30 \\
$\begin{array}{l}\text { (kg/d) } \\
\text { DLWG (kg/head/d }\end{array}$ & 2.80 & 3.30 & 1.70 \\
\hline Sleman, Yogyakarta & 0.11 & 0.14 & 0.15 \\
\hline $\begin{array}{l}\text { Intake of forages (kg/d) } \\
\text { Intake of concentrate }\end{array}$ & 7.60 & 7.60 & 7.60 \\
(kg/d) & 5.20 & 5.81 & 5.47 \\
DLWG (kg/head/d & -0.37 & -0.09 & -0.17 \\
\hline
\end{tabular}

The results at the communal group of Manunggal Karya (Bantul 1) give information on the chemical composition of feed used. Table 11 displays five chemical compositions of feed used in this experiment.

Table 11. Chemical composition of feed based on dry matter $(\%)$.

\begin{tabular}{lccccc}
\hline Kind of Feed & DM & OM & CP & CF & TDN \\
\hline Rice straw & 77.44 & 82.25 & 5.85 & 29.57 & 34.79 \\
Local grass & 52.68 & 86.45 & 3.76 & 29.54 & 47.20 \\
Elephant grass & 48.23 & 84.92 & 4.57 & 15.43 & 47.39 \\
Peanut leaves & 70.23 & 87.91 & 11.09 & 15.43 & 63.90 \\
UMMB & 76.76 & 62.61 & 11.1 & 15.04 & 42.60 \\
Commercial & 88.32 & 84.75 & 14.67 & 4.65 & 42.60 \\
concentrate & & & & & \\
\hline Dry matter & & $:$ & DM & & \\
Organic matter & & $:$ & OM & & \\
Crude protein & $:$ & CP & & \\
Crude fiber & $:$ & CF \\
Total digestible nutrient & $:$ & TDN & & \\
\hline
\end{tabular}

The beef cows received a basal diet which consisted of rice straws, local grass, elephant grass and peanut leaves. The dry matter (DM) content of basal diet consumed was $77.44 \%, 52.68 \%, 48.23 \%$, and $70.23 \%$ respectively. The organic matter $(\mathrm{OM})$ content was $82.25-87.91 \%$. The lowest OM content was found in UMMB, namely $62.61 \%$. The crude 
protein $(\mathrm{CP})$ content in rice straw, local grass and elephant grass were lower than peanut leave, these were $5.85 \%, 3.76 \%$ and $4.57 \%$ compared to $11.09 \%$. It indicates that peanut leaves has an important role to supply protein feed treatment, including commercial concentrate and UMMB which contained $12.14 \%$ and $14.67 \%$ respectively. Crude fiber content in basal diet was $15.43-29.57 \%$, on the other hand, commercial concentrate and UMMB were lower in basal diet consumed, the value were $4.65-15.04 \%$. The highest of total digestible nutrient (TDN) was peanut leaves, it was $63.9 \%$. TDN of rice straw, local grass, elephant grass, commercial concentrate and UMMB was around $34.79-47.39 \%$.

Table 11 shows that the dry matter contents rice straw, local and elephant grass at Bantul 1 were $77.44 \%, 52.68 \%, 48.23 \%$, respectively. These contents were not the same as Hartadi's [28] measurement. The result of DM rice straw, local and elephant grass were $86 \%, 40 \%$, and $28 \%$ [28]. This was caused by age and cutting time [29]. Water content of plants will decrease - the older the plants, the lower its water content [30]. The results of crude protein analysis was different as well as its DM content result (Table 9). Hartadi et al., [28] reported that the crude protein contents of rice straw, local and elephant grass were $3.57 \%, 5.9 \%$, and $8.7 \%$ [28]. This is in line with our finding that there are differences in the crude protein contents in feed. Probably it was due to raping level, growing environment of the plants, time of harvesting, and processing [31].

Measurements of nutrient consumed beef cow showed that most of nutrient consumed differed significantly, except crude fiber consumed. Treatments in Group III showed that the average values of DM, OM, CP and TDN was higher than group II and I, however group II did not differ significantly from Group III (Table 12).

Table 12. The average of $\mathrm{DM}, \mathrm{OM}, \mathrm{CP}, \mathrm{CF}$ and TDN consumed.

\begin{tabular}{lccc}
\hline Consumption of & \multicolumn{3}{c}{ Treatment of } \\
& Group I & Group II & Group III \\
\hline $\mathrm{DM}\left(\mathrm{g} / \mathrm{Kg} \mathrm{W}^{0.75}\right)$ & $99.89^{\mathrm{a}}$ & $112.71^{\mathrm{b}}$ & $120.11^{\mathrm{b}}$ \\
$\mathrm{OM}\left(\mathrm{g} / \mathrm{Kg} \mathrm{W}^{0.75}\right)$ & $84.24^{\mathrm{a}}$ & $92.68^{\mathrm{b}}$ & $99.33^{\mathrm{b}}$ \\
$\mathrm{CP}\left(\mathrm{g} / \mathrm{Kg} \mathrm{W}^{0.75}\right)$ & $7.29^{\mathrm{a}}$ & $9.29^{\mathrm{b}}$ & $9.97^{\mathrm{b}}$ \\
$\mathrm{CF}\left(\mathrm{g} / \mathrm{Kg} \mathrm{W}^{0.75}\right)$ & 24.73 & 25.18 & 26.23 \\
$\mathrm{TDN}\left(\mathrm{g} / \mathrm{KgW}^{0.75}\right)$ & $42.82^{\mathrm{a}}$ & $48.27^{\mathrm{b}}$ & $51.43^{\mathrm{b}}$ \\
\hline
\end{tabular}

Within lines mean different supersecript differed significantly $\mathrm{P}<0.05$.

The feed treatment of medicated block on beef cows located at communal group Bantul 1 gave significant $(\mathrm{P}<0.05)$ positive respond in nutrient intake of $\mathrm{DM}, \mathrm{OM}, \mathrm{CP}$ and TDN. The ration of group III where the treatment with UMMB-MBalbendazole was carried out tend to fulfill nutrient requirement of cows. DM, OM, CP and TDN consumptions were 120.11, 99.33, 9.97, and $51.43 \mathrm{~g} / \mathrm{kg} \mathrm{W}^{0.75} / \mathrm{day}$. The researchers reported that cows on lactation period after calving need DM intake to be $100.16 \mathrm{~g} / \mathrm{kg} \mathrm{W} \mathrm{W}^{0.75}(300 \mathrm{Kg})$ or $100.11 \mathrm{~g} / \mathrm{kg} \mathrm{W}^{0.75}$ [32]. The higher the DM consumption of the cows, the more they consumed other nutrient, such as OM, CP and TDN [33]. This was supported by $\mathrm{CP}$ requirement of cows, which was $9.51 \mathrm{~g} / \mathrm{Kg} \mathrm{W} \mathrm{W}^{0.75}$ day $(300 \mathrm{~kg})$ or $8.91 \mathrm{~g} / \mathrm{Kg} \mathrm{W}^{0.75} / \mathrm{day}(350 \mathrm{Kg})$ [34]. It means that the $\mathrm{CP}$ intake in this experiment exceeded the $\mathrm{CP}$ intake required by cows after calving. In addition, TDN consumption also exceeded the required TDN intake. Some factors which tended to increase nutrient consumption were DM intake, supplementation of UMMB, the better quality of feed consumed, the higher $\mathrm{CP}$ intake, and the tendency that the more DM consumed, the higher the intake of other nutrients [34-36]. Whether TDN was high or low was influenced by the total amount of nutrients digested [28].

The DLWG cows group III tend to be higher than II and I, the value was $0.34 \mathrm{~kg} / \mathrm{head} / \mathrm{d}$ compared to 0.24 and $0.20 \mathrm{~kg} / \mathrm{head} / \mathrm{d}$ respectively, although significant differences were not found (Table 13).

Table 13. Average of DLWG in $\mathrm{kg} / \mathrm{head} / \mathrm{d}$.

\begin{tabular}{cccc}
\hline \multirow{2}{*}{ Repetition } & \multicolumn{3}{c}{ Feed treatment } \\
& Group I & Group II & Group III \\
\hline 1 & 0.16 & 0.18 & 0.31 \\
2 & 0.28 & 0.34 & 0.42 \\
3 & 0.17 & 0.19 & 0.29 \\
Mean value $^{\mathrm{ns}}$ & 0.20 & 0.24 & 0.34 \\
\hline ns: not significant & & &
\end{tabular}

By feeding medicated block treatment, no significantly difference was found in DLWG. However, cows that received medicated block tended to be slower in their DLWG decrease. This was caused by lactating period after calving. When cows have calfs, they usually produce milk for the calf and the nutrient reserve in their body will be more mobilized for milk production. However, in cows that received medicated block, the mobilization of nutrient reserve seem to be slower or lower. Animal condition, age, gender, environment condition, management, palatability and feed consumption have potential roles for increasing daily live weight gain [37]. In addition, physiologically, after calving, cows will utilize energy reserve in their body for milk production, so their body weight always decreases [38]. 
The results of nutrient analysis at communal group Andini Mulyo (Bantul 2) are presented in Table 14.

Table 14. Nutrient contents of feed consumed based on DM $(\%)$.

\begin{tabular}{lccccc}
\hline \multicolumn{1}{c}{ Kind of Feed } & DM & OM & CP & CF & TDN \\
\hline Rice straw & 77.50 & 77.40 & 4.08 & 33.47 & 38.61 \\
Fermented rice & 75.87 & 78.07 & 6.25 & 31.35 & 49.72 \\
straw & & & & & \\
Local grass & 35.69 & 85.81 & 9.33 & 29.89 & 54.27 \\
Elephant grass & 29.99 & 84.92 & 8.79 & 28.46 & 54.16 \\
UMMB & 80.79 & 73.44 & 11.1 & 8.56 & 35.94 \\
Commercial & 86.82 & 86.85 & 8.68 & 15.30 & 59.91 \\
concentrate & & & & & \\
\hline
\end{tabular}

Some parts of the feed consumed were different; it contains not only rice straw, but also included local and elephant grass, as well as fermented rice straw, but no added peanut leaves. The results of nutrient analysis show differences from the nutrient content of feed at Bantul 1; this is shown clearly in crude protein content. The values were $4.08 \%, 6.25 \%, 9.33 \%, 8.79 \%, 11.1 \%$, and $8.68 \%$. Fermented rice straw is capable of increasing crude protein content. In Manunggal Karya and Andini Mulyo, the crude protein content were $5.85 \%$ (Table 11) and $4.08 \%$ and was increased to $6.25 \%$ (Table 14). The crude protein content of fermented rice straw was $6.25 \%$; it was slightly different from the result of other researchers which was $7.72 \%$. This was brought about by the utilization of urea in the processing of fermented rice straw [31]. They also mentioned that fermented rice straw has a good quality in terms of nutrient including chemical composition, digestibility and palatability.

Some of nutrient content feed consumed indicated that there were no significant difference $(\mathrm{P}>0.05)$, such as $\mathrm{DM}, \mathrm{OM}$ and $\mathrm{CF}$, however, $\mathrm{CP}$ and TDN were significantly different $(\mathrm{P}<0.05)$. Treatment of R IV, CP intake was higher than R I, II and III, namely $10.80 \mathrm{~g} / \mathrm{Kg} \mathrm{W}^{0.75}$ vs 7.56, 8.21 and $8.51 \mathrm{~g} / \mathrm{Kg} \mathrm{W} \mathrm{W}^{0.75}$. In addition, TDN intake was significantly different $(\mathrm{P}<0.05)$ and its value was also higher than R I, RII and R III. This was $69.30 \mathrm{~g} / \mathrm{Kg} \mathrm{W}^{0.75}$ vs $57.41,61.11$ and $61.28 \mathrm{~g} / \mathrm{Kg}$ $\mathrm{W}^{0.75}$ (Table 15).

Table 15. The average of $D M, O M, C P, C F$ and $T D N$ in $\mathrm{g} / \mathrm{Kg} \mathrm{W}^{0.75}$.

\begin{tabular}{lcccc}
\hline Consumption of & \multicolumn{4}{c}{ Feed treatments } \\
& R I & R II & R III & R IV \\
\hline $\mathrm{DM}\left(\mathrm{g} / \mathrm{Kg} \mathrm{W}^{0.75}\right)$ & 122.6 & 130.09 & 130.24 & 134.06 \\
$\mathrm{OM}\left(\mathrm{g} / \mathrm{Kg} \mathrm{W}^{0.75}\right)$ & 99.22 & 105.70 & 107.53 & 108.22 \\
$\mathrm{CP}\left(\mathrm{g} / \mathrm{Kg} \mathrm{W}^{0.75}\right)$ & $7.56^{\mathrm{a}}$ & $8.21^{\mathrm{a}}$ & $8.51^{\mathrm{a}}$ & $10.08^{\mathrm{b}}$ \\
$\mathrm{CF}\left(\mathrm{g} / \mathrm{Kg} \mathrm{W}^{0.75}\right)$ & 34.65 & 36.55 & 35.48 & 34.09 \\
$\mathrm{TDN}\left(\mathrm{g} / \mathrm{Kg} \mathrm{W}^{0.75}\right)$ & $57.41^{\mathrm{a}}$ & $61.11^{\mathrm{ab}}$ & $61.28^{\mathrm{ab}}$ & $69.30^{\mathrm{b}}$ \\
\hline
\end{tabular}

Within lines, means different superscript differed significantly $(\mathrm{P}<0.05)$.
The DLWG seem to decrease and it did not differ significantly $(\mathrm{P}>0.05)$, however its value of $\mathrm{R}$ IV tend to be higher than R I and R III. Its value was $-0.05 \mathrm{~kg} / \mathrm{head} / \mathrm{d}$ vs -0.27 and $-0.12 \mathrm{~kg} / \mathrm{head} / \mathrm{d}$ (Table 16).

Table 16. The average of body weight alteration $(\mathrm{kg} / \mathrm{head} / \mathrm{d})$.

\begin{tabular}{lccrr}
\hline Repetition & \multicolumn{4}{c}{ Feed treatment } \\
& R I & R II & R III & \multicolumn{1}{c}{ R IV } \\
\hline 1 & -0.30 & -0.20 & 0.10 & -0.16 \\
2 & -0.28 & 0.03 & -0.15 & -0.03 \\
3 & -0.24 & 0.18 & -0.30 & 0.03 \\
Average value $^{\text {ns }}$ & -0.27 & 0.003 & -0.12 & -0.05 \\
\hline
\end{tabular}

ns: not significant

Beef cows were maintained at Andini Mulyo (Bantul 2) and only differed significantly in CP and TDN consumed. Basal diet + fermented rice straw + concentrate + UMMB-MB albendazole (R IV) tend to fulfill the nutrient requirement of the cows. DM, $\mathrm{OM}, \mathrm{CP}$ and TDN consumed were obtained as $134.06,108.22,10.08$ and $69.30 \mathrm{~g} / \mathrm{Kg} \mathrm{W}^{0.75} /$ day. Nutrient requirement of beef cow is positive balance as well as beef cows at Bantul 1.

Result of total amount of worm egg count was not significant, however, based on time period of albendazole treatment, total amount of worm egg decreased from 18.66 to $2.42 \mathrm{~g}$, when counted from zero to 10 days, after that it increased $7.33 \mathrm{~g}$ on 30 days (Table 17).

Table 17. Total of worm egg/gram

\begin{tabular}{lcccc}
\hline Feed & \multicolumn{4}{c}{ Faeces samples on day } \\
treatment & 0 & 10 & 30 & Mean values \\
\hline R I & 30.66 & 5.33 & 10.33 & 15.44 \\
R II & 13.33 & 0.00 & 11.33 & 8.22 \\
R III & 18.00 & 2.00 & 3.33 & 7.77 \\
R IV & 12.66 & 2.33 & 4.33 & 6.64 \\
Mean values & $18.66^{\mathrm{a}}$ & $2.42^{\mathrm{ab}}$ & $7.33^{\mathrm{ab}}$ & \\
\hline
\end{tabular}

Within lines, means with different superscript differed significantly $(\mathrm{P}<0.05)$.

Medicated block tend to respond positively to decrease of total amount worm egg in faeces. The decrease was shown on ten days, and then increased in 30 days. Medicated block seem to be effective only for ten days; after that it was not able to decrease the total amount of worm egg. Two factors tend to influence it, namely feed supplied and power of medical effect. Weather has potential role in the decrease or increase of parasite population [39]. Dry seasons with high temperatures and more sunlight is capable of breaking parasite life cycle [39]. On the other hand, rainy season, with high humidity, will increase parasite population. The maximal effectiveness of anthelmintics given to cows was only 10 days. 


\section{CONCLUSION}

The tracer P-32 has potential role for biological evaluation ruminant feed and UMMBSBM has a positive impact farmers incomes. Their income increased based on cost benefit ratio. There did not appear to be any advantage in the inclusion of $C$. aeruginosa in the UMMB formulation as an anthelmintic since this formulation did not improve animal output compared to UMMB alone. The formulation containing albendazole was capable of increasing nutrients consumed and milk production. Further work is required to confirm this finding.

\section{ACKNOWLEDGMENT}

This work could not be carried out without the generous financial support from National Nuclear Energy Agency (BATAN), representing the Government of Indonesia. The authors wish to thank Ms. Dra. Cornelia Hendratno and all members of the working groups in South Sulawesi, West Sumatra, and Jakarta, for their efforts and commitment during the implementation of the project. Gratitude is also expressed to Prof. Elsye L. Sisworo and Prof. Sugiarto Danu for editing to this paper and C. Ellen Kusumaningrum and others who helped during this project and those who contributed to this paper.

\section{REFERENCES}

1. C. Hendratno, J.V. Nolan and R.A. Leng, The Importance of Urea-Mollases Multinutrient Blocks for Ruminant Production in Indonesia, Proceedings of an International Symposium on Nuclear Techniques in Animal Production and Health, Joint by International Atomic Energy Agency and Food and Agriculture Organization of United Nation (1991) 157.

2. R. Leng A., Application of Biotechnology to Nutrition of Animals in Developing Countries, FAO Animal Production and Health 90, United Nation (1997) 69.

3. C. Hendratno, The use of ${ }^{32} P$ and ${ }^{35} S$ as Tracer for Measuring Microbial Protein Mass in Rumen Liquid Buffaloes, Nuclear Technique Application in Agriculture and Livestock Field, Proceedings of Siecentific Seminar 1984, BATAN (1985) 609.

4. C.J. Van Nevel and D.I. Demeyer, British J. Nutrition 38 (1977) 101.
5. Anonymous, Report of Program Activity of Region Technology Science (RTC), Proceeding of RTC National Nuclear Energy Agency (2000) 1. (in Indonesian)

6. Anonymous, Report of Program Activity of Region Technology Science (RTC), Proceeding of RTC National Nuclear Energy Agency (2001) 1. (in Indonesian)

7. Anonymous, Report of Program Activity of Region Technology Science (RTC), Proceeding of RTC National Nuclear Energy Agency (2002) 1. (in Indonesian)

8. H.P.S. Makkar, Feed Supplementation Block Technology-past, Present and Future, in: Feed Supplementation Blocks, Urea-Molasses Multinutrient Block: Simple and Effective Feed Supplement Technology for Rumunant Agriculture, FAO Animal Production and Health 164 (2007) 1.

9. M.A.S. Khan, M.A.R. Chowdhhury, M.A. Akbar, et al., Urea Molasses Multinutrient Block Technology-Bangladesh Experiences, in: Feed Supplementation Blocks, Urea-Molasses Multinutrient Block: Simple and Effective Feed Supplement Technology for Rumunant Agriculture, FAO Animal Production and Health 164 (2007) 75.

10. J.X. Liu, R. Long and D. Zhang. Feed Supplementation Blocks-experiences in China, in: Urea Molasses Multinutrient Block Technology-Banguladesh Experiences, Feed Supplementation Blocks, Urea-Molasses Multinutrient Block: Simple and Effective Feed Supplement Technology for Rumunant Agriculture, FAO Animal Production and Health 164 (2007) 89.

11. M.R. Knock, Nematode Parasitism of Cattle and Buffalo: Prospect for Control using Medicated Urea-Molasses Blocks, in: Urea Molasses Multinutrient Block TechnologyBangladesh Experiences, Feed Supplementation Blocks, Urea-Molasses Multinutrient Block: Simple and Effective Feed Supplement Technology for Rumunant Agriculture, FAO Animal Production and Health 164 (2007) 233.

12. P.K. Sanyal, D.K. Singh and M.R. Knox, Buffalo Journal 3 (1993) 265.

13. Anonymous, Report of Program Activity of Region Technology Science (RTC), Proceeding of RTC National Nuclear Energy Agency, Banten (2003) 1. (in Indonesian) 
14. R.G. Steel, D. J.H. Torrie, Principles and Procedures of Statistics: A Biometrical Approach, $2^{\text {nd }}$ ed., McGraw-Hill Book Company, London (1980) 137.

15. E.J. Soulsby and L. Helminths, Arthropods and Protozoa of Domesticated Animals, $7^{\mathrm{nt}}$ ed. English Language Book Society and Bailliere Tindall London (1982) 773.

16. Suharyono, C. Hendratno, H.S. Bintara, et al., Bulletin of Animal Husbandry, Special edition, (1993) 193. (in Indonesian)

17. Suharyono, T. Maryati and N. Lelananingtyas. The Utilization of Legume Leaf, Soy Waste Sauce, Soy Bean Meal as Goat Feed for Reducing the use of $U M M B$, Proceedings of Scientific Seminar Application of Isotopes and Radiation, Book III, Animal Husbandry, Biology and Chemistry (1994) 57. (in Indonesian)

18. Suharyono, H.S. Bintara, A. Syamsi, et al., The use of Leaves of Legume Tree and Bypass Protein as a Supplement Feed on Ruminant Animal, Proceedings of Sciencetific Seminar on Appliaction of Isotopes and Radiation, Book III, Livestock, Biology and Chemistry (1996) 25. (in Indonesian)

19. Suharyono, Biological Value Evaluation and Leaves Mineral Content of Gliricidia Maculata and Enterolobium Cyclocarpum as Feed Supplement with Isotope P-32 Radio and Neutron Activation Analysis, Proceeding of the National Seminar of Animal Husbandry and Veterinary (1998) 643. (in Indonesia)

20. R Leng A., S.H. Bird, A. Klieve, et al., The Potential for Tree Forage Supplements to Manipulate Rumen Protozoa to Enhance Protein to Energy Ratios in Ruminants Fed on Poor Quality Forages, Proceedings of the FAO 844 Expert Consultation Held at the Malaysian Agricultural Research and Development Institute (MARDI) (1992) 177.

21. F. Haloman, R. Priyanto and H. Nuraeni, J. Animal Science and Technology Med. Pet. 24 (2001) 12. (in Indonesian)

22. Suharyono, Development and Introducing of Feed Supplement for Ruminant Feed to Farmers, Nuclear Technology Science of Bunga Rampai, Scientific presentation of Madya/Principal Researchers Vol. 1, No. 1, Center for the Dissemination Nuclear Technology Science - BATAN (2010) 1. (in Indonesian)
23. Anonymous, ATOMOS (2005) 1. (in Indonesian)

24. M.C.N. Jayasurya and T. Smith, Guidelines for Developing Feed Supplementation Packages. Animal Production and Health Section Joint FAO/IAEA Division IAEA, Vienna, Austria (1997) 8.

25. Suharyono, M.P. Eko and E. Erawan, Multi nutrient feed supplement: A high nutrient feed supplement for ruminant animals, Center of Dissemination of Nuclear Science and Technology BATAN (2005) 1. (in Indonesian)

26. Anonymous, Report of test result No.LHP.01.11/047/03/2008, Quality Feed Assay Laboratory, National Standard of Indonesia (SNI) 01-2891-1992 Item 5.1 (2008). (in Indonesian)

27. SJ. Gross, WG Ryan and H.W. Ploeger, Veterinary record 144 (1999) 581.

28. H. Hartadi, S. Reksohadiprodjo and A.D. Tilman, Table of Feed Material Composition, $4^{\text {th }}$ ed., Gajah Mada University Press, Yogyakarta (1997) 8. (in Indonesian)

29. A.D. Tillman, H. Hartadi, S. Reksodiprodjo, et al., Science of Basic Animal Feed, $2^{\text {nd }}$ ed., Gajah Mada University Press, Yogyakarta (1998) 12. (in Indonesian)

30. L.C. Kartadisastra, Provision and Ruminant Animal Feed Processing, $1^{\text {st }}$ ed., Kanisius Yogyakarta Press (1997). (in Indonesian)

31. A. Agus, R. Utomo, Ismaya, et al., Bulletin of Livestock 24 (2000) 147. (in Indonesian)

32. I.W. Mathius, M.M. Rangkuti and A. Djayanegara, Consumption Capacity And Digestibility of Sheep on Glyricidae Leaf, Livestock Research Agency, Bogor (1981) 48.

33. L.C Kearl, Nutrients Requirements of Ruminants in Developing Countrries, International Feed Stuffs Institute Utah Agricultural Experimental Station, Utah State University (1982) 45.

34. I.W. Sudiarta, J. Livestock Sci. 2 (1999) 7.

35. U.A. Rohkhayati, The Effect of Energy and Undergraded Protein on Production and Milk Quality of Dairy Cattle Friesian Holstein, Thesis, Gajah Mada University (2004) 33. (in Indonesian)

36. J. Wahyu, Poultry Science 2 (2001) 1. (in Indonesian) 
37. Anonymous, National Research Council. Nutrient Requirement of Beef Cattle, $6^{\text {th }}$ ed., National Academy of Science, Washington DC. (1984) 45.

38. D. Pasambe, M. Sariubang, A. Nurhayu, et al., The Effect of Feed Supply on Bali Cattle Female after calving on Daily Live Weight Gain of Calf, Proceedings of National Seminar Livestock and Veterinary, Research and Development Agriculture Agency, Bogor (2000) 224. (in Indonesian)

39. Subronto and I. Tjahajati, Animal Disease Science II, Gajah Mada University Press. Yogyakarta (2001) 73. (in Indonesian) 